\title{
Phylogenetics of Leptocereus (Cactaceae) on Hispaniola: clarifying species limits in the L. weingartianus complex and a new species from the Sierra de Bahoruco
}

\author{
Lucas C. Majure', Yuley Encarnación ${ }^{1,2}$, Teodoro Clase ${ }^{3}$, \\ Brígido Peguero ${ }^{3}$, Kelly $\mathrm{Ho}^{2}$, Duniel Barrios ${ }^{4}$
}

I University of Florida Herbarium (FLAS), Florida Museum of Natural History, Gainesville, FL 32611, USA 2 Department of Biology, University of Florida, Gainesville, Florida, USA 3 Departamento de Botánica, Jardin Botánico Nacional "Dr. Rafael M. Moscoso", Santo Domingo, Dominican Republic 4 Grupo de Ecología y Conservación, Jardín Botánico Nacional, Universidad de La Habana, Habana, Cuba

Corresponding author: Lucas C. Majure (lmajure@floridamuseum.ufl.edu)

Academic editor: A. Calvente | Received 9 October 2020 | Accepted 15 December 2020 | Published 29 January 2021

Citation: Majure LC, Encarnación Y, Clase T, Peguero B, Ho K, Barrios D (2021) Phylogenetics of Leptocereus (Cactaceae) on Hispaniola: clarifying species limits in the L. weingartianus complex and a new species from the Sierra de Bahoruco. PhytoKeys 172: 17-37. https://doi.org/10.3897/phytokeys.172.59497

\begin{abstract}
The Antillean genus Leptocereus represents an in-situ radiation among the Greater and Lesser Antilles of 19 currently recognized species. Extensive fieldwork carried out in the Dominican Republic over recent years has revealed that the species limits of Leptocereus of Hispaniola are more complex than previously thought. There are four currently recognized species that occur on the island, L. demissus, L. paniculatus, L. undulosus and L. weingartianus. We evaluate species limits in this group based on DNA sequence data and phylogenetic analysis, morphological characters and a survey of herbarium specimens from across Hispaniola. Based on our analyses, it is clear that at least five species occur on the island of Hispaniola, with the new species from Sierra de Bahoruco, L. velozianus, described here. We provide an identification key, distribution maps and photographic plates for all species on Hispaniola based on our own fieldwork and the study of herbarium specimens. The description of yet another species of Leptocereus on Hispaniola reiterates the importance of the poorly studied, but yet biodiverse, seasonally dry tropical forest in the Antilles.
\end{abstract}

\section{Keywords}

Biodiversity, Greater Antilles, plastome phylogeny, Seasonally Dry Tropical Forest

Copyright Lucas C. Majure et al. This is an open access article distributed under the terms of the Creative Commons Attribution License (CC BY 4.0), which permits unrestricted use, distribution, and reproduction in any medium, provided the original author and source are credited. 


\section{Introduction}

Seasonally dry tropical forests (SDTF) are one of the most threatened forest types on the planet with only around $10 \%$ of their original coverage still remaining intact in the Neotropics (Banda-R. et al. 2016) mostly owing to anthropogenic pressures, such as charcoal production and agriculture (Pennington et al. 2000, 2004). This forest type is extensive throughout the Greater Antilles; however, it has been poorly studied (Gentry 1982; Pennington et al. 2005) compared to other forest types on the islands or dry forest from other parts of the Neotropics. Recent work has revealed that these understudied forests have much undocumented biodiversity (e.g., Mejía and García 1997; Fryxell and Clase 2007; Areces-Mallea 2017, 2018; Majure et al. 2020; Martínez-Gordillo et al. 2020). Cactaceae are a conspicuous element of the diverse SDTF of the Greater Antilles, with roughly 94 taxa occurring in the region (Majure et al. unpubl. data). An estimated 35 species occur on the island of Hispaniola, including the Caribbean endemic Leptocereus (A. Berger) Britton \& Rose. Leptocereus s.l. is a clade of 19 currently recognized species of trees and erect to sprawling shrubs, and represents an in-situ Antillean radiation that occurs in SDTF, primarily of the Greater Antilles, where it is most diverse, but also occurs in the Lesser Antilles on the island of Anegada (Barrios et al. 2020). Recent phylogenetic work by Barrios et al. (2020) showed that the two large tree species endemic to Cuba and Hispaniola, and traditionally circumscribed in the genus Dendrocereus (Britton and Rose 1920; Anderson 2001; Hunt et al. 2006), formed a monophyletic group [the Dendrocereus clade (D)] clearly nested within Leptocereus. Barrios et al. (2020) also resolved two other primary clades in Leptocereus, the Cuban (CU) clade consisting of species endemic to Cuba, and the Hispaniolan-Puerto Rican (EPR) clade consisting of taxa endemic to Hispaniola, Puerto Rico and outlying islands.

On Hispaniola, three species of Leptocereus (including Dendrocereus) were formerly recognized (L. paniculatus (Lam.) D. R. Hunt, L. undulosus (DC.) D. Barrios \& Majure, and L. weingartianus E. Hartmann), and Areces-Mallea (2017) recently described a fourth species (L. demissus Areces) from southwestern Dominican Republic from the SDTF south of the Sierra de Bahoruco mountain range. Thus, currently, four species are recognized on Hispaniola.

Barrios et al. (2020) showed that the Hispaniolan endemic, Leptocereus weingartianus, was sister to a clade containing another Hispaniolan endemic, L. paniculatus, and a clade of two Puerto Rican species, L. grantianus Britton and L. quadricostatus Britton \& Rose. Leptocereus weingartianus is widely distributed across Hispaniola and is morphologically heterogeneous, forming relatively large shrubs or small trees (ArecesMallea 2017) with apical branches that are often sprawling among surrounding, dense vegetation of SDTF (Majure et al. pers. obsv.). The new species, L. demissus, described by Areces-Mallea (2017), is morphologically very similar to L. weingartianus, especially considering the sprawling growth form of ultimate stem segments (Majure et al. pers. obsv.), however, several reproductive characters appear to separate the two species morphologically (Areces-Mallea 2017). Recent fieldwork in the Sierra de Bahoruco has 
revealed populations of an unidentified taxon of what morphologically appeared to be part of the L. weingartianus complex, however, which differed from typical L. weingartianus in stem and spine features. Therefore, it was clear given the morphological heterogeneity of $L$. weingartianus, and the wide distribution and phenetic similarity of putative close relatives, such as $L$. demissus, that phylogenetic analyses of these taxa on Hispaniola were greatly needed.

We wanted to determine whether the morphologically disparate populations from the Sierra de Bahoruco were indeed closely related to the L. weingartianus complex, and whether or not the morphologically similar $L$. demissus was distinct from $L$. weingartianus based on phylogenetic relationships. We sampled multiple populations of typical $L$. weingartianus, one population of the newly described $L$. demissus and several populations of the new morphotype from Sierra de Bahoruco, as well as taxa from all major clades of Leptocereus (sensu Barrios et al. 2020) and carried out a phylogenetic reconstruction based on nearly entire plastome sequencing from genome skimming. We also reviewed herbarium specimens from across the distribution of Leptocereus on Hispaniola, and we herein provide distribution maps, photographic plates, and an identification key to all species on Hispaniola, as well as a description of the new species uncovered during this work.

\section{Materials and methods}

All species of Leptocereus from Hispaniola, representing the EPR and D clades, as well as the new material from Sierra de Bahoruco, were sampled here for phylogeny reconstruction along with three taxa from the CU clade of Leptocereus and the Cuban L. nudiflorus (Britton \& Rose) D.Barrios \& S.Arias of the D clade. Likewise, L. grantianus and $L$. quadricostatus of the EPR clade were sampled. Outgroups included here were based on previous work by Barrios et al. (2020) and Majure et al. (unpubl. data) and included Armatocereus, Calymmanthium, Cereus, Melocactus, Selenicereus, and Stenocereus of Core Cactoideae (see Appendix 1).

Whole genomic DNAs of all taxa were extracted using a standard CTAB protocol with silica column cleaning (see Majure et al. 2019; Köhler et al. 2020). DNAs were resuspended in $300 \mathrm{ul}$ of TE (Tris-EDTA) buffer ( $\mathrm{pH}$ 8.0), and DNA quantity was analyzed on a Qubit 2.0 Fluorometer. Whole genomic DNAs were sent to Rapid Genomics LLC (http://rapid-genomics.com/home/; Gainesville, Florida, U.S.A.) for library preparation (including shearing) and sequencing via a genome skimming method, as in Majure et al. (2019). All taxa were sequenced on the Illumina HiSeq X platform using paired end reads (yielding $150 \mathrm{bp}$ reads), and sixty samples were included per lane.

Raw reads of all taxa were imported in to Geneious (v. 11.1.5, Biomatters Ltd., Auckland, New Zeland) and reference-mapped using a previously, de-novo assembled partial plastome (including the large-single copy unit) of Melocactus pedernalensis M.M.Mejía \& R.G.García (Majure, unpubl. data). Consensus sequences were then generated from reference-mapped plastomes, which were used for alignments. 
Sequence alignment was carried out using the MAFFT (Katoh and Standley 2016) plugin in Geneious. We analyzed our 104,697 bp dataset (including indels) under maximum likelihood (ML) with the RAxML (Stamatakis 2014) plugin in Geneious using the rapid bootstrapping algorithm and undertaking 100 bootstrap pseudoreplicates.

Specimens (ca. 50) from multiple herbaria (JBSD, NY, S, US), as well as those generated from our own fieldwork (DES, FLAS, JBSD), were consulted for determining the morphological distinctiveness of the new material from the Sierra de Bahoruco, as compared to the phenetically similar taxa $L$. weingartianus and L. demissus. Those data also were used to determine the distribution of all species of Leptocereus across Hispaniola and to generate our identification key to the species (in part).

\section{Results}

Leptocereus s.l. was resolved as monophyletic in our phylogenetic analysis, and all three principal subclades recovered by Barrios et al. (2020) were recovered here as well (i.e., CU, D, and EPR subclades)-all three subclades were mostly well-supported (CU, bs = $100 \%$; D, bs $=84 \%$, EPR, bs $=100 \%)$. The CU subclade was sister to a well-supported clade (bs $=100 \%$ ) composed of the D and EPR subclades. Multiple accessions of the two species composing the D clade, L. undulosus and L. nudiflorus formed clades and were resolved as sister taxa in our topology, further demonstrating their phylogenetic distinctiveness. Within the EPR clade, a clade composed of L. demissus and the new species $L$. velozianus was sister to a clade composed of two subclades, the first formed by all accessions of $L$. weingartianus and the second by $L$. paniculatus, $L$. grantianus and $L$. quadricostatus. Thus, our results show that $L$. weingartianus is not closely related to the new species $L$. velozianus, but rather more closely related to the rest of the EPR clade. Likewise, although $L$. demissus appears to be phenetically more similar to L. weingartianus, it was more closely related to the new species $L$. velozianus. In all cases where multiple accessions were used per species, those species formed well-supported clades (Fig. 1).

Leptocereus velozianus (Figs 2, 3), which is restricted to the northwestern part of the Sierra de Bahoruco (Fig. 4), is slightly phenetically similar to the Puerto Rican species L. quadricostatus, given the crenate rib margins and spiny pericarpels, although those two species are not close relatives (Fig. 1). Leptocereus velozianus is most phenetically similar to two other Hispaniolan species (L. weingartianus and L. demissus - Figs 5, 9), especially $L$. weingartianus, but differs from them based on the spine color (white or cream versus yellow to yellowish-red, although, younger spines in L. velozianus can be yellow-cream colored with darker tips, thus slightly overlapping with $L$. weingartianus), and the overall size of the joints $(1.2-3.5 \mathrm{~cm}$ in diameter in the latter two species and 2.7-3.7 in L. velozianus). Leptocereus velozianus has conspicuously crenate margins, generally more so than either $L$. weingartianus or $L$. demissus, although this is a variable character (Areces-Mallea 2017). Although Areces-Mallea (2017) mentioned that $L$. demissus has straight rib margins between areoles and $L$. weingartianus is more 


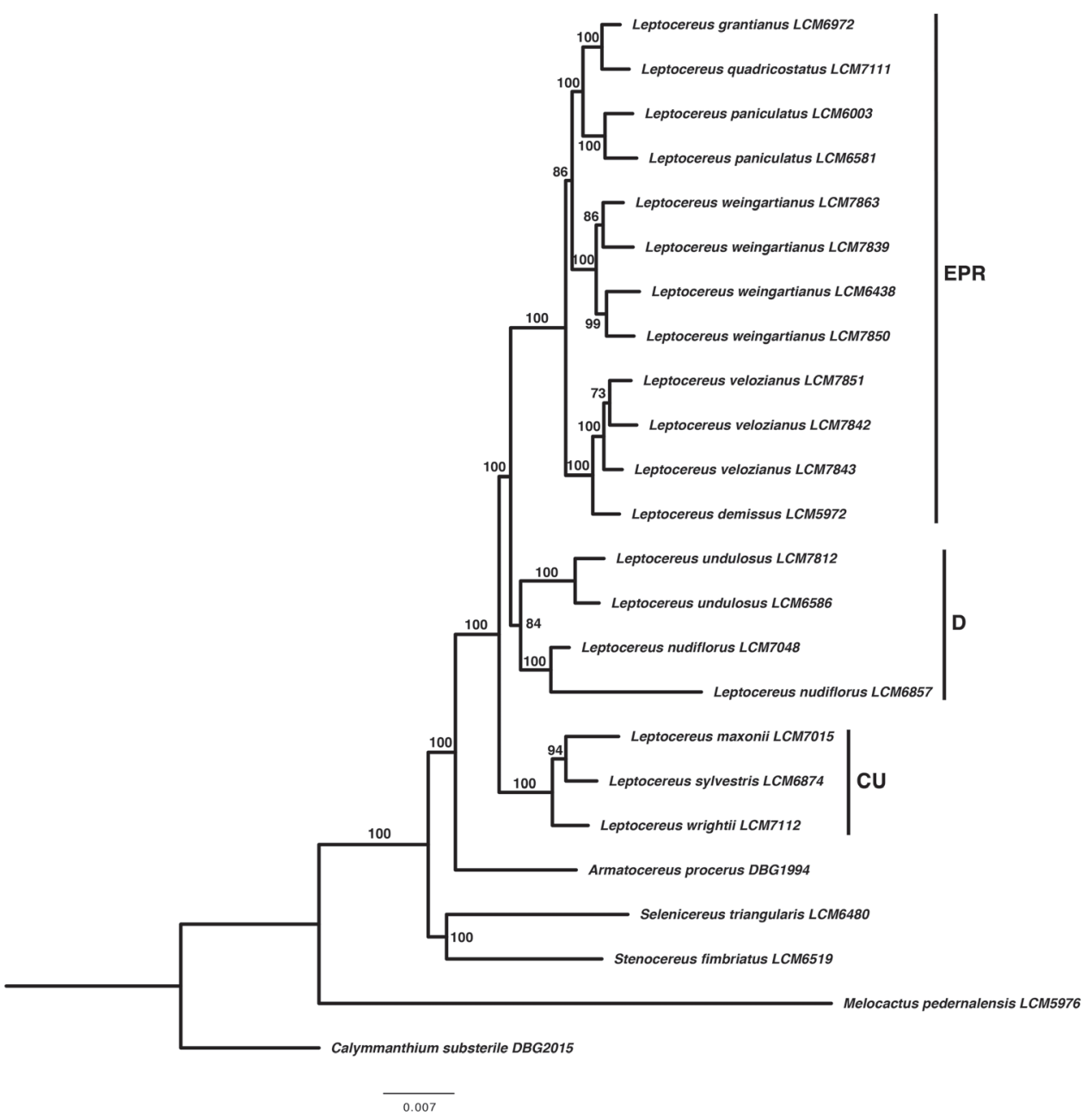

Figure I. Phylogeny of Leptocereus with all major clades represented (sensu Barrios et al. 2020) and the new species $L$. velozianus included, resolved here as sister to $L$. demissus. Bootstrap values are given above the branches.

crenate, we found that character to be variable in both, with L. weingartianus also sometimes having nearly straight rib margins between areoles (Figs 5B, 9A). In general, L. velozianus can be separated from the other two species, L. demissus and L. weingartianus, by a suite of morphological characters, as well as its phylogenetic relationships to the other taxa (Fig. 1). Leptocereus velozianus does not share any major morphological features with either L. paniculatus or L. undulosus (Figs 6, 7).

As far as is known, L. demissus and L. velozianus are the most restricted species on Hispaniola, with $L$. demissus restricted to lower elevation dogtooth limestone of Parque Nacional Jaragua and the surrounding area south of the Sierra de Bahoruco, while L. velozianus is restricted to well-developed tropical dry forest along the north slopes 
of the Sierra de Bahoruco (Fig. 4). Leptocereus paniculatus, L. undulosus, and L. weingartianus are much more widespread, with $L$. weingartianus occurring mostly on the north island from its eastern extremity near Cabo Engaño to its western extremity in Haiti on Gonave Island in elevations ranging from near sea level to $755 \mathrm{~m}$ in the Sierra Martín García, Dominican Republic (see Additional specimens examined). Leptocereus paniculatus is quite widespread across the island and is mostly found at lower elevations from -30 m on Isla Cabritos to around 400 m near Sierra Martín García, while L. undulosus is mostly restricted to areas near the coast in elevations ranging from near sea level to $245 \mathrm{~m}$ (Fig. 8, see also additional specimens examined).

\section{Discussion}

Our topology differs only slightly from Barrios et al. (2020) in that the CU clade was sister to the rest of Leptocereus here, whereas, in Barrios et al. (2020) the EPR clade was sister to the rest of Leptocereus. In both topologies, the D clade was nested within Leptocereus. Although it has been suggested that L. undulosus and L. nudiflorus may be conspecific (Anderson 2001), the multiple accessions sampled here clearly show them as genetically distinct entities, with multiple accessions of each forming clades, this likely being further driven by their reproductive isolation, being restricted to Hispaniola and Cuba, respectively. Morphological characters separating these two taxa are currently under investigation (D. Barrios unpubl. data).

Our phylogenetic results clearly demonstrate that the new species described here, L. velozianus, is genetically distinct from the more widespread $L$. weingartianus, and L. demissus, likewise, is more closely related to L. velozianus rather than the phenetically more similar $L$. weingartianus. Areces-Mallea (2017) mentioned that $L$. demissus is physically separated from $L$. weingartianus by the Sierra de Bahoruco. Our phylogenetic results and fieldwork support this idea, given that all $L$. weingartianus sampled were collected north of the Sierra de Bahoruco and form a well-supported clade, however, $L$. weingartianus does occur in the southern peninsula at nearly the same latitude as L. demissus south of Massif de la Hotte in Haiti based on the proposed neotype of L. weingartianus by Areces-Mallea (2017) from Cote le Fer. Interestingly, L. weingartianus grows alongside L. velozianus in the Sierra de Bahoruco; however, we have seen no evidence of hybridization between the two species. Ploidy, though, has not been examined in any species of Leptocereus from Hispaniola but is currently underway. Leptocereus weingartianus also occurs alongside L. paniculatus in populations near Jimaní and L. demissus occurs with L. undulosus in Parque Nacional Jaragua; however, we likewise have seen no putative hybrids among those species' pairs. We consider that phenology and perhaps pollinator differences could be driving the lack of hybridization in Leptocereus on Hispaniola (although we have very little information on specific pollinators of these species), and in other parts of their ranges, $L$. weingartianus appears to occupy different ecological niches than $L$. paniculatus. For example, in the Sierra Martín García, although both species occur there, L. paniculatus occurs at much 
lower elevations than L. weingartianus, which begins to be found around $400+$ meters (Majure et al. pers. obvs.). So, ecology also could be driving species divergence in this group of close relatives.

Below, we provide a description of the new species, L. velozianus, as well as a taxonomic treatment with identification key, distribution maps and photographic plates of the other four species of Leptocereus on Hispaniola. Updated descriptions of the other four species will be presented elsewhere (Encarnación, in prep.).

\section{Taxonomic treatment}

\section{Key to the species of Leptocereus on Hispaniola}

$1 \quad$ Large trees, floral buds and fruit spineless

- Small trees, erect or sprawling shrubs, floral buds and fruit spiny (at least when immature) ...................................................................... 3

2 Mature stem segments mostly spineless, usually 3-4-ribbed, fruit broadly ovate to elliptic, smooth. L. undulosus

- $\quad$ Mature stem segments spiny, 4-5-ribbed, fruit elliptical, tuberculate

3 Stems $1.2-3.5 \mathrm{~cm}$ in diameter, ribs crenate or straight, young spines yellow to yellowish-red 4

- $\quad$ Stems $2.7-3.7 \mathrm{~cm}$ in diameter, ribs strongly crenate, young spines white to cream L. velozianus Small trees or erect shrubs (ultimate stem segments often sprawling in age), stems mostly 4-5 ribbed, hypanthium oblong L. weingartianus - $\quad$ Sprawling shrubs, stems 5-7 ribbed, hypanthium obconic L. demissus

\section{Leptocereus velozianus Clase, Y.Encarn., Peguero \& Majure, sp. nov.} urn:Isid:ipni.org:names:77214766-1

Figs 2-4

Type. República Dominicana. Prov. Independencia. Sierra de Bahoruco, Parque Nacional Sierra de Bahoruco, Puerto Escondido, Rabo de Gato, 433 m, 14 mayo 2019, Majure 7843 (Holotype: JBSD!, Isotype: FLAS!).

Diagnosis. Differing from both L. weingartianus and L. demissus by the white young spines (vs. yellowish spines) and larger stem diameter (up to $3.7 \mathrm{~cm}$ in diameter in L. velozianus). Differing from L. demissus by the erect, primary trunk rather than the sprawling growth form, and oblong hypanthium in L. velozianus rather than obconic hypanthium as in L. demissus.

Description. Erect shrubs or small trees 2-4 m tall, ultimate stem segments often sprawling among associate vegetation in smaller individuals, or merely pendent on larger individuals, $13-40+\mathrm{cm}$ long, $2.7-3.7 \mathrm{~cm}$ wide, ribs $4-5$ per stem, $12-17 \mathrm{~mm}$ 
deep, rib margins strongly crenate, $18-28 \mathrm{~mm}$ between areoles, spines white (or yellowish around the developing base), aging gray, tips brownish-red to black, 13-15 per areole, erect, central spine 16-22 mm long, longest radial spines $18-30 \mathrm{~mm}$ long, shortest pair of reflexed radial spines at base of areole, 3-6 mm long, a tuft of brown, crisped trichomes filling areoles; flower, including hypanthium, ca. $7.6 \mathrm{~cm}$ long, spiny, outer tepals green, inner tepals greenish-white, apices obtuse, anthers white, $1.3-1.5 \mathrm{~mm}$ long, style ca. $3 \mathrm{~cm}$ long, stigma included in the corolla, lobes 8 , pale green, apparently at the level of the ring of anthers, nectar chamber about $8 \mathrm{~mm}$ wide, immature fruit, 5-7.5 × 2.6-3.4 cm (excluding dried perianth), lustrous green, spiny, areoles ca. 28-36, with 8-13 spines, those $3-12 \mathrm{~mm}$ long, strongly brownish-red and white banded, the tips dark brownish-red to black, seeds 3.3-3.7 × 2.3-2.5 mm, dull black (only appearing shiny when not cleaned) with colliculate-pitted surface.

Etymology. The specific epithet, "velozianus" is given honoring the Dominican botanist Alberto Veloz, who is the Head and Curator of the Herbarium JBSD of the "Dr. Rafael M. Moscoso" National Botanical Garden of Dominican Republic. For 27 years, Veloz has dedicated his life to the study of the Hispaniolan flora and has conducted extensive fieldwork across the island, with many collections from the Sierra de Bahoruco, where this new species was found. Together with other botanists he has collected over 10,000 specimens and has published several papers on the flora in national and international journals. His publications have included different approaches, such as floristics, taxonomy, ecology and conservation. Veloz has also contributed to the formation of young botanists by involving students as part of the staff in the herbarium JBSD and through fieldwork.

Distribution and habitat. Leptocereus velozanius grows in well-formed, seasonally dry tropical forest over limestone from around $158-433 \mathrm{~m}$ in elevation occurring with the following associate species: Bursera simaruba Sarg., Celtis ehrenbergiana (Klotzsch.) Liebm., Coccoloba diversifolia Jacq., Consolea microcarpa (K.Schum.) E.F.Anderson, Cordia globosa Kunth, Cylindropuntia caribaea (Britton \& Rose) F.M.Knuth, Eugenia rhombea (O.Berg.) Krug \& Urb., Gouania lupuloides Urb., Guaiacum sanctum L., Helicteres semitriloba Bert. ex DC., Hybanthus havanensis Jacq., Krugiodendron ferreum Urb., Leptocereus weingartianus (E.Hartmann) Britton \& Rose, Melochia tomentosa L., Opuntia repens Bello, Pisonia aculeata L., Phyllostylon rhamnoides (J.Poiss.) Taub., Prosopis juliflora (Sw.) DC., Senna angustisiliqua (Lam.) H.S.Irwin \& Barneby, Senegalia skleroxyla (Tussac) Seigler \& Ebinger, Tournefortia stenophylla Urb., Zanthoxylum nashii P.Wilson, Ziziphus rignonii Delponte. Currently, the species is only known from the northwestern slope of the Sierra de Bahoruco, southwest of the town of Jimaní (Fig. 4). Given the extent of tropical dry forest in and around that area, it is very likely that more localities of this species will be found.

Phenology. Leptocereus velozianus has been collected in flower and immature fruit during May and with mature fruit in June, July and November. Thus, it appears likely that $L$. velozianus may flower over the early to mid-summer months with fruit ripening later in the year. 


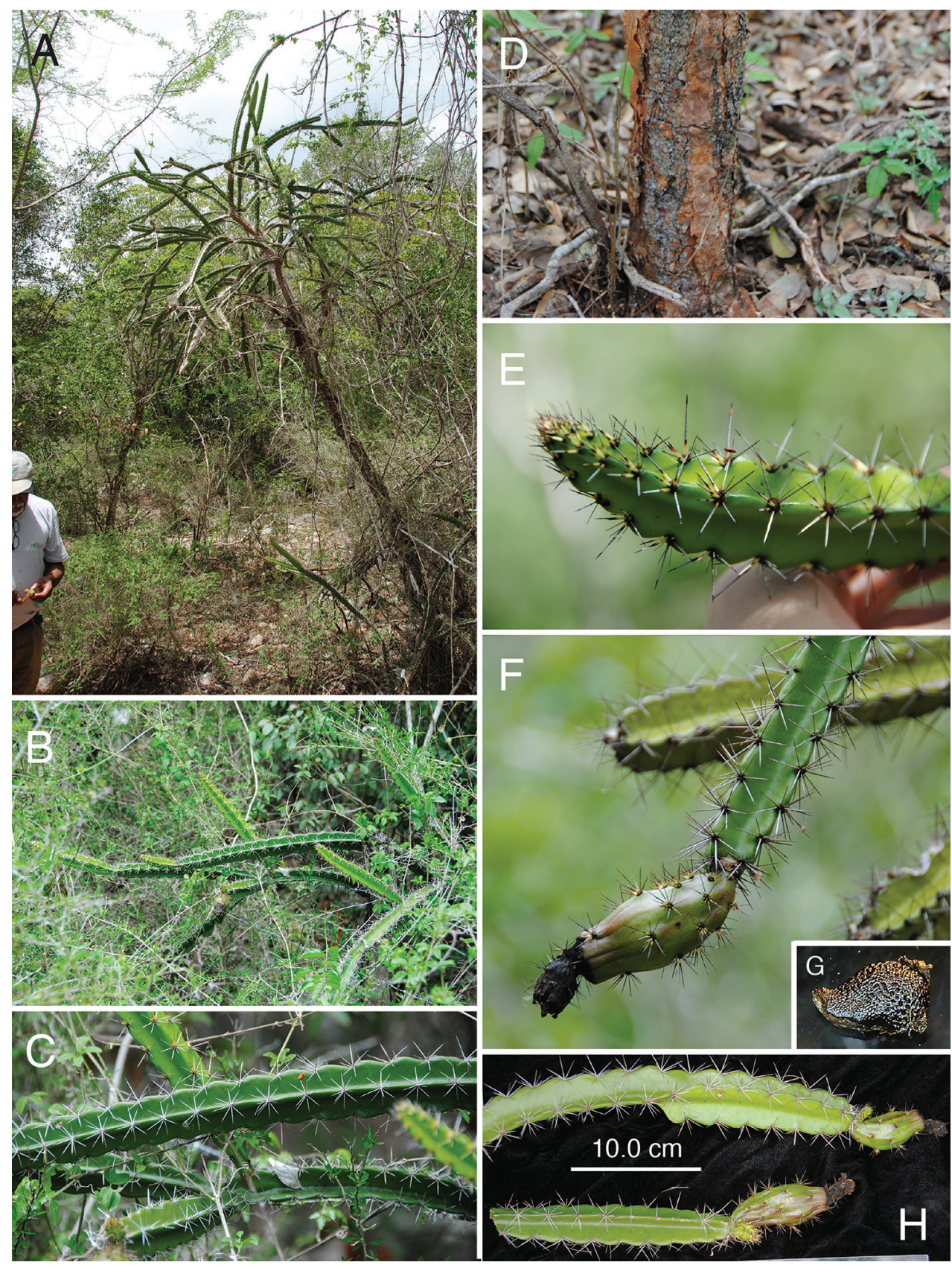

Figure 2. Photographic plate of L. velozianus $\mathbf{A}$ small tree habit of L. velozianus alongside T. Clase for scale $\mathbf{B}, \mathbf{C}$ arching branches and spine color $\mathbf{D}$ trunk and bark $\mathbf{E}$ growing stem showing white spines as they mature $\mathbf{F}$ spiny, immature fruit $\mathbf{G}$ colliculate-pitted seed, and $\mathbf{H}$ stems with immature fruit, showing crenate rib margins. A, D, F, G from Majure 7851 B, C, H from Majure 7843, and E from Majure 7842. Photos taken by L.C. Majure. 


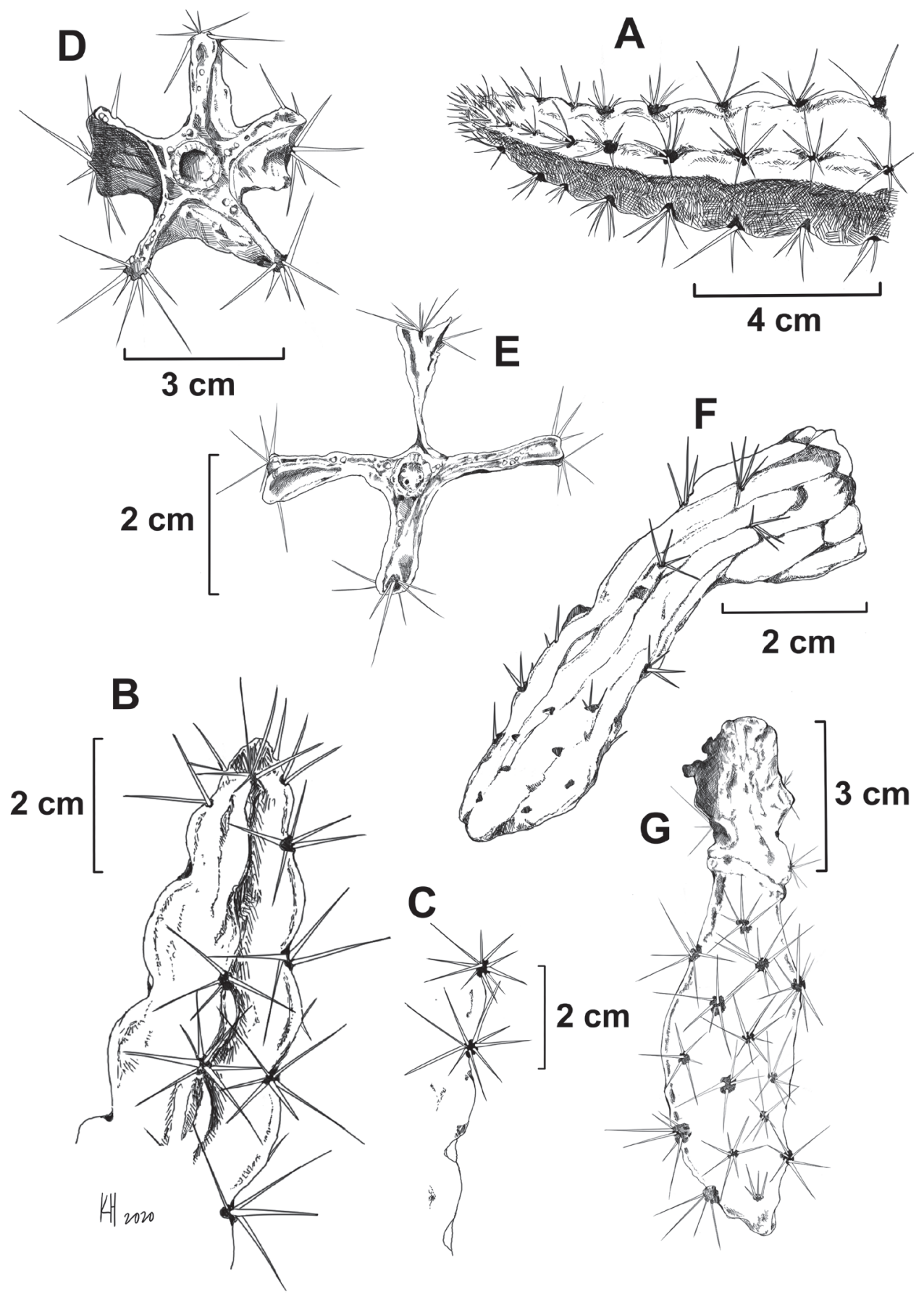

Figure 3. Illustration of $L$. velozianus $\mathbf{A}-\mathbf{C}$ stems showing crenate margins $\mathbf{D}, \mathbf{E}$ cross sections showing 4-5 ribbed stems, also showing large crystals in the parenchyma $\mathbf{F}$ day old flower showing rounded external tepal apices and spiny pericarpel, and $\mathbf{G}$ immature fruit showing spiny pericarpel and remnant floral tube. A from Majure 7842, and B-F from Majure 7843. 
Conservation status. Formal evaluation of conservation status will be undertaken by Encarnación (in prep.) for L. velozianus based on further field work and demographic study. However, based on the currently known limited distribution of the species, the few numbers of individuals that have been observed, as well as anthropogenic activity near populations of the species, we consider that this species could be Near Threatened based on IUCN criteria. Further fieldwork will be essential for providing a comprehensive assessment of the conservation status of L. velozianus. Fortunately, the larger population known for this species is within the Sierra de Bahoruco National Park, so it is mostly protected from large-scale anthropogenic disturbances. Furthermore, the SDTF in that area is very well developed (i.e., non-fragmented) and should provide extra protection for the species.

Additional specimens examined. Dominican Republic. Prov. Independencia. Sierra de Bahoruco, municipio Duvergé, comunidad Puerto Escondido, lugar denominado Rabo de Gato, yendo hacia Cañada de Pedro Bello, 26 jun 2013, Clase et al. 8004 (JBSD). Sierra de Bahoruco, municipio Duvergé, Rabo de Gato, yendo hacía la cañada La Cuaba, Pedro Bello, 23 nov 2017, Clase et al. 9931 (JBSD). Sierra de Bahoruco, municipio Duvergé, Puerto Escondido, lugar denominado Rabo de Gato, yendo hacía la Cañada de Pedro Bello, 27 jul 2017, Clase et al. 10202 (JBSD). Sierra de Bahoruco, municipio Jimaní, yendo desde El Limón, lugar denominado Guzmán, lado Sur de la carretera, 27 jul 2017, Clase et al. 10205 (JBSD). Sierra de Bahoruco, justo al Este de Jimaní en la carretera 46 (entre Jimaní y El Limón) en el lugar denominado Guzmán; 158 m, 14 mayo 2019, Majure 7842 (FLAS, JBSD). Parque Nacional Sierra de Bahoruco, Puerto Escondido, Rabo de Gato; 433 m, 14 mayo 2019, Majure 7851 (FLAS, JBSD).

\section{Leptocereus demissus Areces Cactus Succ. J. (Los Angeles) 89: 118. 2017.} Figs 4, 5

Type. Dominican Republic. Prov. Pedernales. On limestone terraces of maritime origin along both sides of the road to Pedernales, approx. $10 \mathrm{~km}$ southeast of Cabo Rojo, in dry forests dominated by large Dendrocereus undulosus trees, 22 Dec. 1998, Areces 6812 (Holotype: JBSD-n.v.; Isotypes: NY, HAJB, HNT-n.v.).

Notes. Although type material of $L$. demissus is reported to be at JBSD, HAJB, HNT, and NY (Areces-Mallea 2017), we have been unable to locate types at any of these institutions for comparative analysis for this work. Thus, we have based our knowledge on the morphological traits of this species using those characters given by Areces-Mallea (2017), geography, and the one collection from near Oviedo made by us (Majure 5972-see specimens examined; Fig. 5).

Additional specimens examined. Dominican Republic. Prov. Pedernales. Oviedo, Sierra de Bahoruco, Municipio Oviedo, lugar denominado Fondo Paradí, Parque Nacional Jaragua, 86 m, 3 feb 2016, Majure 5972 (DES, JBSD). Cabo Rojo, próx. al punto No. 7 de la Concesión, [no date], Veloz et al. 945 (JBSD). A 18 km de Oviedo en la carretera hacia Pedernales, 1 mayo 1998, Villardebó s.n. (JBSD). 


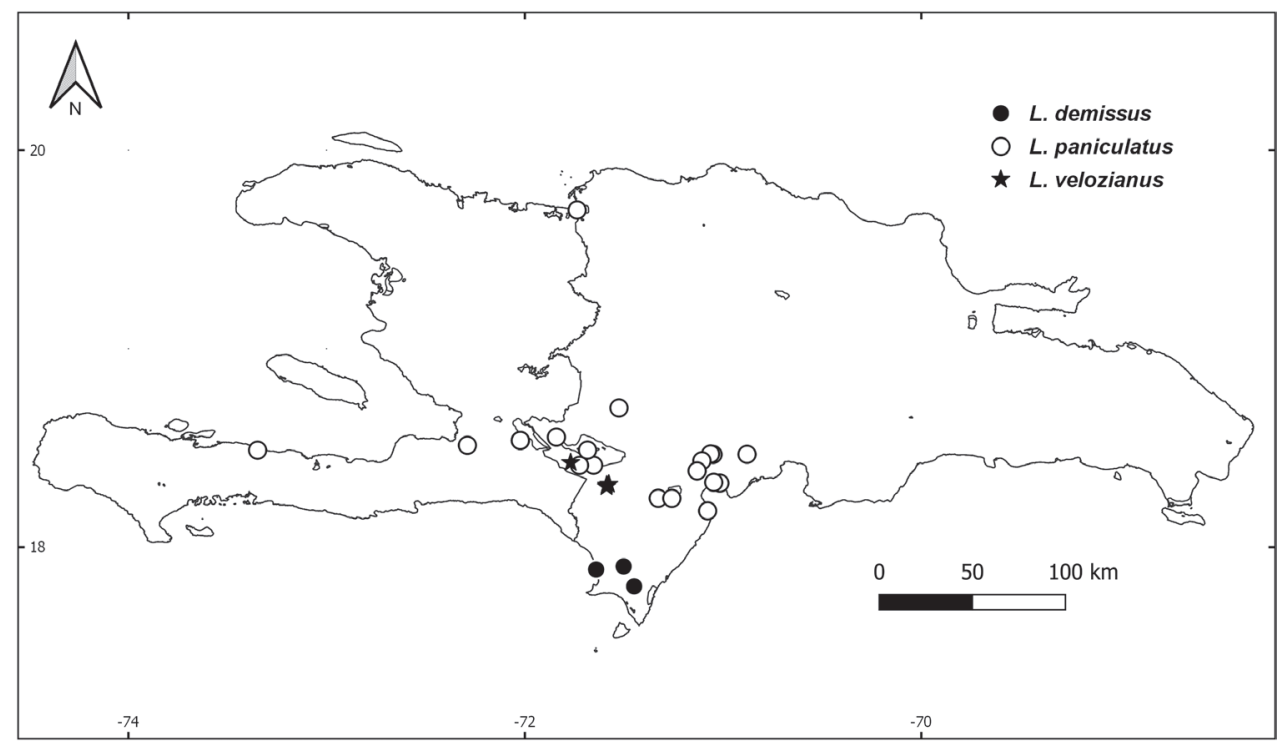

Figure 4. Distribution map of $L$. demissus (black circles), L. paniculatus (open circles), and L. velozianus (black stars) on Hispaniola.
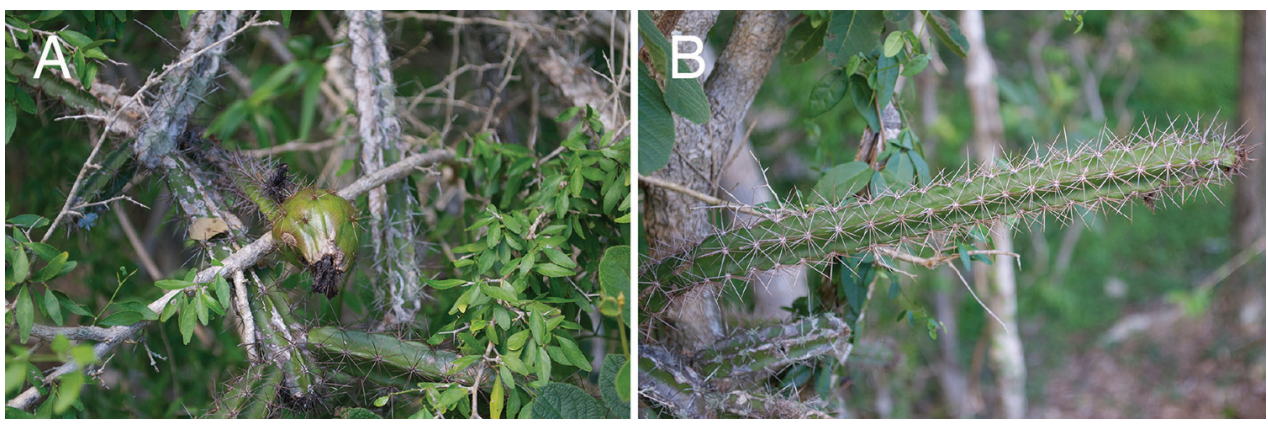

Figure 5. Photographic plate of $L$. demissus $\mathbf{A}$ spiny fruit, and B slightly crenate stem of $L$. demissus (from Majure 5972). Photos by L.C. Majure.

\section{Leptocereus paniculatus (Lam.) D. R. Hunt Bradleya 9: 89. 1991.} Figs 4,6

Cactus paniculatus Lam. Encyl. [J. Lamarck \& al.] 1: 540. 1785. Cereus paniculatus (Lam.) DC. Prodr. [A. P. de Candolle] 3: 466. 1828. Neoabbottia paniculata (Lam.) Britton \& Rose Smithsonian Misc. Collect. 72: 3. 1921.

Type. Presumably from near Cul de Sac, Haiti, where Plumier collected numerous species. Lectotype (designated by Mottram 2002), plate t.21 in Plumier, which was cited by Lamarck (1785) and thus formed part of the protologue. This includes an illustration of a fragment of a stem segment, flower and fruit. 

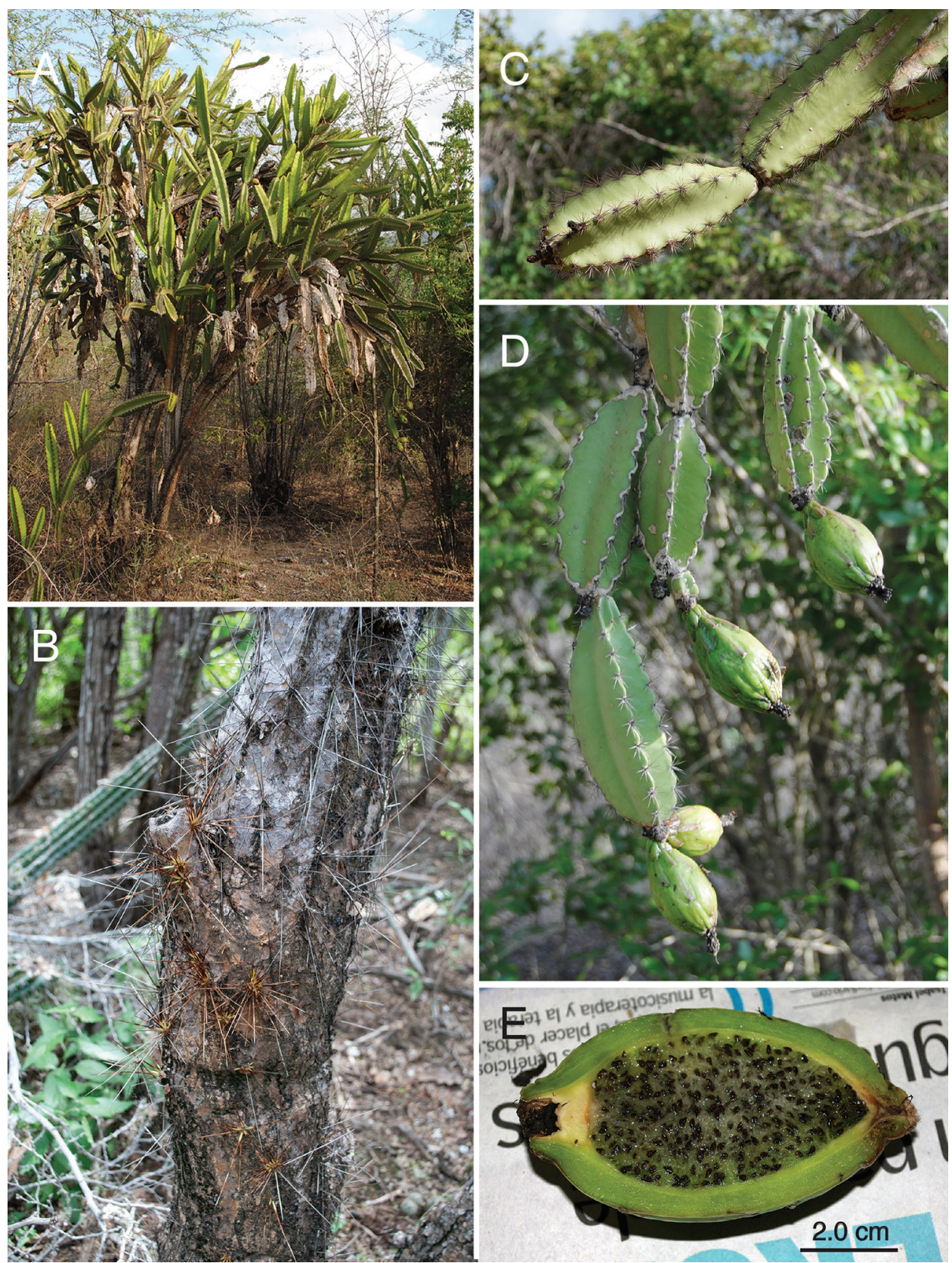

Figure 6. Photographic plate of L. paniculatus A habit B spiny trunk $\mathbf{C}$ apical, spiny, four-angled stems $\mathbf{D}$ fruiting stems and tuberculate fruit, and $\mathbf{E}$ longitudinal section of mature fruit. A, D from Majure 7817 B, C, E from Majure 6581. Photos by L.C. Majure.

Notes. Leptocereus paniculatus is consistently recovered as closely related to the L. quadricostatus/L. grantianus clade (Fig. 1; see also Barrios et al. 2020), although the species is much more robust and treelike compared to the other two species. It is the 
only species on Hispaniola that has spineless, tuberculate fruits and forms large populations at lower elevations in seasonally dry tropical forest across the island (Figs 4, 6).

Additional specimens examined. Dominican Republic. Prov. Azua. Llanura de Azua, $4 \mathrm{~km}$ al oeste del poblado de Tábara Abajo, en la carretera hacía Barahona, 400 m, 2 sept 1994, García et al. 5630 (JBSD). Provs. Azua-Barahona. Este de Quita Coraza en el camino a Azua, 25 mayo 1982, Zanoni \& Mejía 20797 (JBSD). Provs. Baoruco-Barahona. A $3 \mathrm{~km}$ al este del poblado de Quita Coraza, 500 m, 10 dic 1994, Perdomo \& Villafaña 18 (JBSD). Prov. Barahona. $1.5 \mathrm{~km}$ al sur del poblado Fondo Negro, siguiendo un camino en dirección suroeste, 100 m, 15 oct 1994, Camejo et al. 31 (JBSD). Barahona, 1913, Fuertes 13.19 (NY, on 3 sheets). Sierra Martín García, approx $1.5 \mathrm{~km}$ al S del Higuito, 120 m, 16 dic 1995, García et al. 6119 (JBSD). Sierra Martín García, ca $0.6 \mathrm{~km}$ al noreste del Cruce Vicente Noble, al costado de un arroyo seco justo al este de la Carretera 44., 108 m, 3 nov 2016, Majure 6581 (DES, JBSD). Along road between Canoa and Puerto Alejandro, 5-20 m, 17 Oct 1982, Proctor 39106 (JBSD). Prov. Independencia. Municipio Jimaní, distrito municipal Boca de Cachón, parte arriba del balneario, lugar denominado la Loma, 4 m, 6 jun 2009, Clase et al. 5638 (JBSD). Sierra de Neiba, Ángel Félix, 400 m, 24-26 mar 1975, Liogier et al. 22786 (JBSD). Entre Duvergé y Cabral, 3 ene 1977, Liogier 26214 (JBSD). Independencia, Sierra de Bahoruco, al lado (sur) del Lago Enriquillo, al oeste ca. $15 \mathrm{~km}$ de Duvergé en la carretera 46, 5 feb 2016, Majure 6003 (DES, FLAS, JBSD). Justo al sur de la Laguna Rincón ca. $2.5 \mathrm{~km}$ al oeste de La Lista y $3.4 \mathrm{~km}$ al este de Las Salinas a lo largo de la Carretera 46, 104 m, 13 mayo 2019, Majure 7817 (FLAS, JBSD). Sierra de Bahoruco, ca. $1.5 \mathrm{~km}$ al este de El Limón en la Carretera 46 al sur del Lago Enriquillo, $43 \mathrm{~m}, 13$ mayo 2020, Majure 7840 (FLAS, JBSD). Isla Cabritos en el Lago Enriquillo, próximo al Campamento de Parques Nacionales, -30 m, 14 oct 1981, Mejía \& Pimentel 17261 (JBSD). Prov. Montecristi. Pepillo Salcedo (Manzanillo), al este del pueblo, en la zona donde se desarrollará el proyecto Puerto Cristal, 5 m, 5 nov 2002, García \& Gómez 7512 (JBSD). HarTI. [Dept. de Nippes]. Massif de la Hotte, western group, Anse a Veau, quaternary limestone west of town, 2 Jan 1936, Ekman H5393 (NY). Dept. de l'Ouest. Vicinity of Etang Saumatre, 4-12 Apr 1920, Leonard 3500a-b (NY, US). Ibid, Leonard 5344 (NY, US). Vicinity of Petionville, 350 m, 15-28 Jun 1920, Leonard 5326 (NY).

\section{Leptocereus undulosus (DC.) D. Barrios \& Majure, Plant Syst. Evol. 306: 12. 2020. Figs 7, 8}

Cereus undulosus DC., Prod. Syst. Nat. 3: 467. 1828. Dendrocereus undulosus (DC.) Britton \& Rose, J. New York Bot. Gard. 26(310): 220. 1925. Acanthocereus undulosus (DC.) Croizat, Caldasia 2: 137. 1943.

Lectotype. (designated by Barrios et al. 2020): illustration in Plumier, Plantarum americanarum fasc. 8. 187. t. 194. 1758. Epitype. (designated by Barrios et al. 2020): Haiti, Jean Rabel Rd., vicinity of Cabaret, Baie des Moustiques, plain west of Cabaret, 12-18 Jan 1929, E.C. Leonard \& G.M. Leonard 12085 (NY 03305544!). 


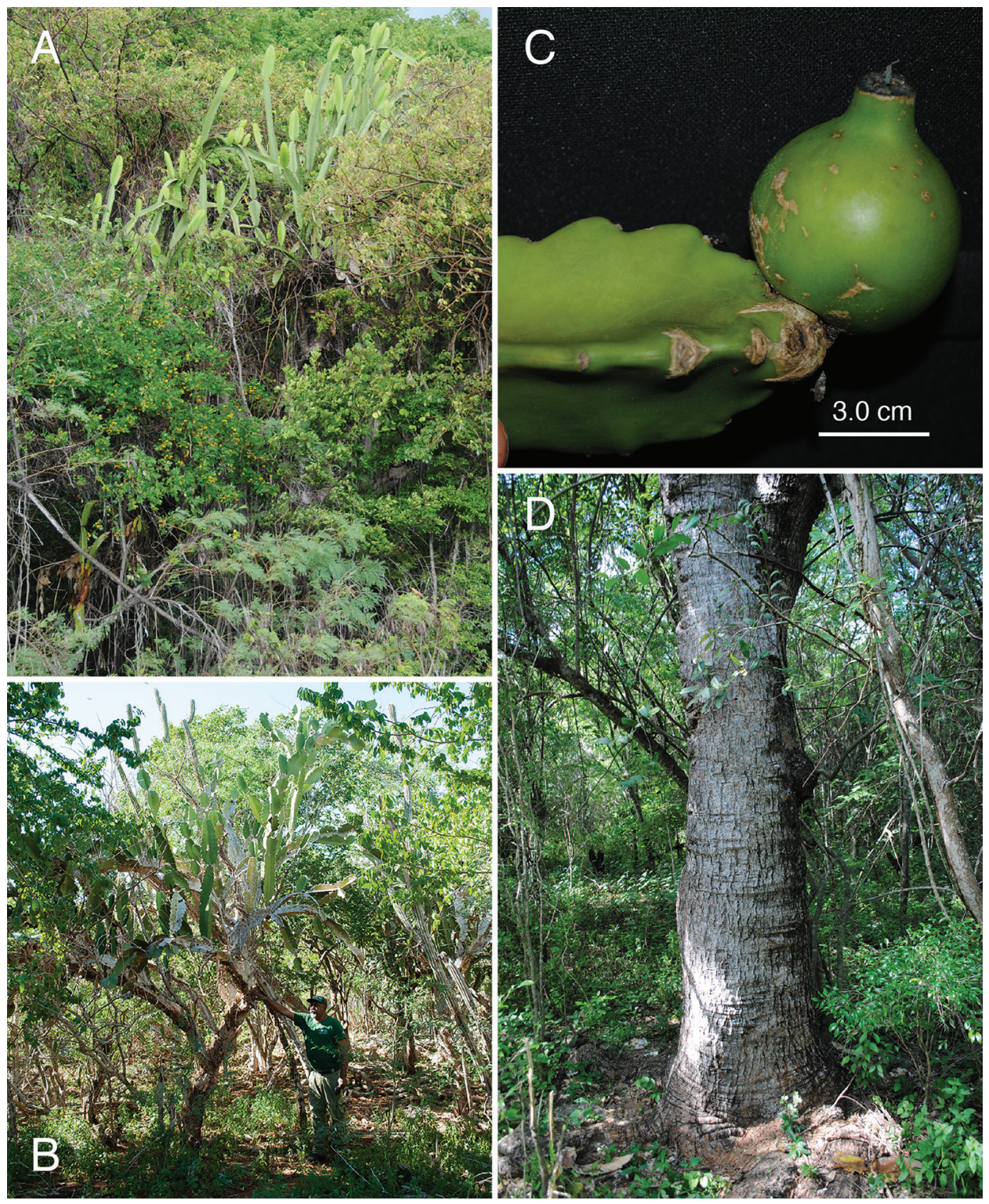

Figure 7. Photographic plate of $L$. undulosus $\mathbf{A}$ large tree of $L$. undulosus erupting from surrounding tropical dry forest $\mathbf{B}$ small individual of $L$. undulosus with T. Clase for reference $\mathbf{C}$ fruit and three-angled stem $\mathbf{D}$ large, woody trunk (ca. $>64 \mathrm{~cm}$ dbh). A from Majure 7812 B, D from Majure. 6586 and $\mathbf{C}$ from Majure 5974. Photos by L.C. Majure.

Notes. Although several authors have suggested that L. undulosus may be conspecific with L. nudiflorus of Cuba (Anderson 2001, Hunt et al. 2006), Barrios et al. (2020) showed that the two taxa were sister to one another and likewise were genetically divergent; however, they only sampled one accession of L. undulosus. We reaffirm 
that relationship here with one more sample of $L$. undulosus included in our phylogenetic analysis from a population near Barahona, east of the previous accession used in Barrios et al. (2020) from Parque Nacional Jaragua. Both samples form a strongly supported clade, sister to L. nudiflorus. More detailed morphological studies are necessary across the populations of $L$. undulosus on Hispaniola. Considering the distance between populations of the two (Cuba vs. Hispaniola), it is very likely that they are reproductively isolated. Thus, there seems to be no reason to consider these two taxa as conspecific. We anticipate that further morphological and genetic study will provide further support for the recognition of these two species.

Although not represented in our distribution map of L. undulosus, as there are no collections from that site, Île de la Tortue likely represents one of the larger populations of the species on Hispaniola (Peguero pers. obsv.). This reiterates the extensive fieldwork that still needs to be carried out to fully document populations of species of cacti with herbarium specimens from across the island. Cacti are often uncommonly collected because of the difficulty in preparing specimens, and thus, are generally poorly represented in herbaria (Majure et al. 2017).

Additional specimens examined. Dominican Republic. Prov. La Altagracia. $500 \mathrm{~m}$ al sur del cruce hacia Bayahibe en la carretera al Parque Nacional del Este, $60 \mathrm{~m}$, 22 mayo 1986, García \& Pimentel 1051 (JBSD). Prov. Barahona. Sierra de Bahoruco, a lo largo de Carretera 44, ca. $0.8 \mathrm{~km}$ al norte de Playa Azul, 13 mayo 2019, Majure 7812 (FLAS, JBSD). Prov. Pedernales. Entre Pedernales y Oviedo, 150 m, 24-27 jun 1975, Liogier \& Liogier 23339 (JBSD). Oviedo, Paraje Tres Charcos, Parque Nacional Jaragua, área de sisal, 138 m, 3 feb 2016, Majure 5974 (DES, FLAS, JBSD). Oviedo, Parque Nacional Jaragua, al suroeste de Manuel Goya y Carretera 44, Lugar denominado "Los Sisales", cerca $14.6 \mathrm{~km}$ al oeste de Oviedo, $245 \mathrm{~m}, 16$ nov 2016, Majure 6586 (DES, JBSD). En la carretera hacia Las Mercedes, desde Pedernales a $2.5 \mathrm{~km}$ del cruce, 1 mayo 1998, Villardebó s.n. (JBSD). Haitr. Dept. de l'Ouest. Massif de la Selle, group Morne des Commissaires, Anses-a-Pitre, limestone cliff at Río Pedernales, on the road to Banane, 25 Oct 1926, Ekman H6730 (NY). Place de la Paix, Port au Prince, no date, Buch? (NY). Dept. de Nord-Ouest. Coastal terrace between Mole St. Nicholas and Jean Rabel, 19 Jan 1995, Areces 6790 (S). Between Port-des-Paix and Moustique, 1924, Buch s.n. (NY).

\section{Leptocereus weingartianus (E.Hartmann) Britton \& Rose Cactaceae 2: 77. 1920.} Figs 8, 9

Cereus weingartianus E. Hartmann Monatsschr. Kakteenk. 14: 155. 1904.

Type. Haiti. Lectotype (designated by Barrios and Majure, in review). Photo of type material of L. weingartianus in Hartmann (1904).

Notes. There has been some confusion around the type of $L$. weingartianus - Areces-Mallea (2017) designated a neotype of L. weingartianus considering that the original 


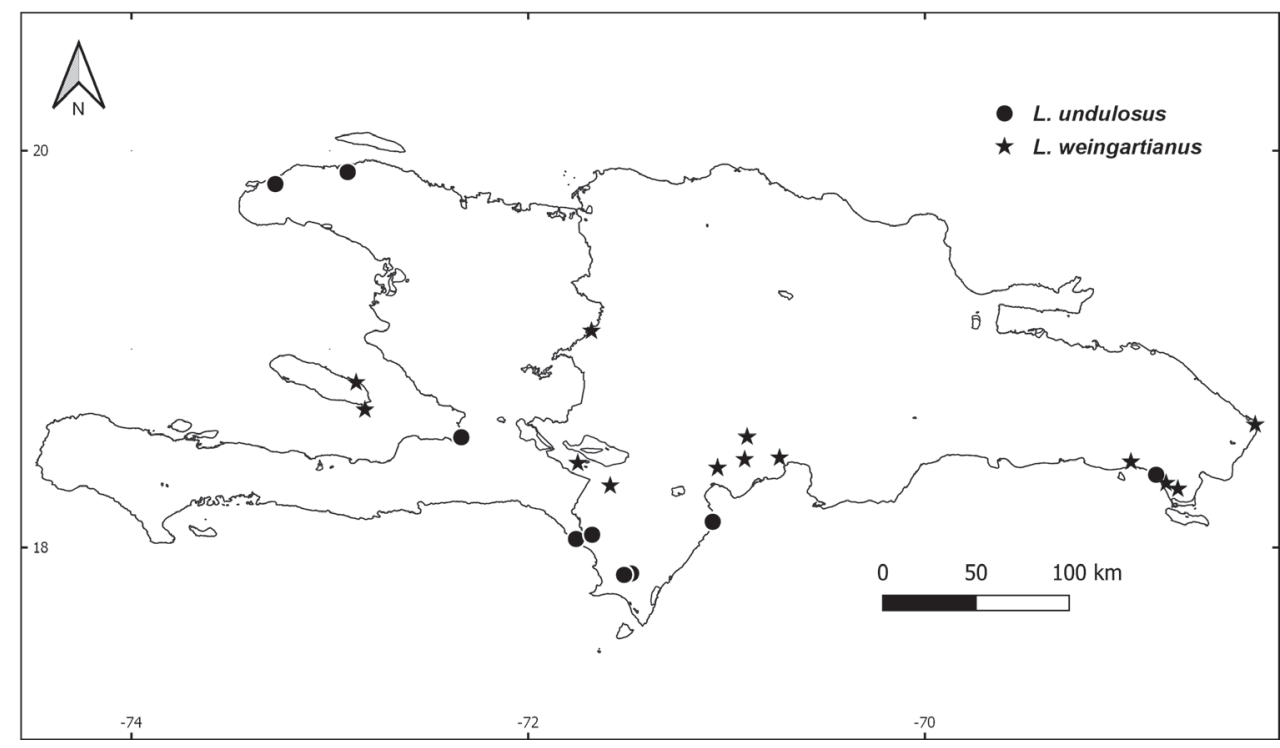

Figure 8. Distribution map of L. undulosus (black circles) and L. weingartianus (black stars) on Hispaniola.

type specimen is likely not extant, however, the photo of the type material in the protologue (Hartmann 1904) represents original material (Fig. 9C) and thus should serve as the type for this species. Thus, the neotype designation by Areces-Mallea (2017) from Cote le Fer, Haiti, is superfluous. Although supposedly deposited in JBSD and NY, we have been unable to find those specimens. Likewise, we have been unable to locate the other specimens of L. weingartianus (Areces 5973, 6438, 6814, 6815, 6875) cited by Areces-Mallea (2017) and supposedly at NY, so those are not cited in our specimens examined here.

Additional specimens examined. Dominican Republic. Prov. La Altagracia. Bayahíbe, La Romana, 1-5 m, 21 Feb 1976, Liogier \& Liogier 24907 (JBSD, NY). Cabo Engaño, on coastal road, 14 May 1980, Mejía \& Zanoni 6299 (JBSD). Parque Nacional del Este, Sector Guaraguao, 21 ene 1986, Salazar et al. 317 (JBSD). Parque Nacional del Este, en el camino hacía La Cueva de José María, Guaraguao, 1-30 m, 28 abr 2001, Veloz \& Cedeño 2648 (JBSD). Prov. Azua. Municipio Sabana Yegua, después del cruce del 15, yendo hacía San Juan, aprox. $600 \mathrm{~m}$ antes del poblado de Las Guanábanas, 241 m, 30 jul 2011, Clase et al. 6824 (JBSD). Sierra Martín García, Sept 1976, Liogier 25277 (JBSD). Azua, Mar 1913, Rose et al. 3941 (NY, US). Prov. Barahona. Barahona, Sierra Martín García, ca. $0.6 \mathrm{~km}$ al noreste del Cruce de Vicente Noble, al noreste ca. $11.2 \mathrm{~km}$ de la Carretera 44, a lo largo del un arroyo seco, 685 m, 3 nov 2016, Majure 6438 (DES, JBSD). Sierra Martín García, ca. 0.6 km al noreste del Cruce de Vicente Noble, al noreste ca. $11.2 \mathrm{~km}$ de la Carretera 44, a lo largo del un arroyo seco, 755 m, 3 nov 2016, Majure 6464 (DES, JBSD). Prov. Elías Piña. Cerro San Francisco (lado del sur), afuera del poblado de Bánica al sur de Pedro Santana, 490 m, 14 mayo 2019, Majure 7863 (FLAS, JBSD). Prov. Independencia. 

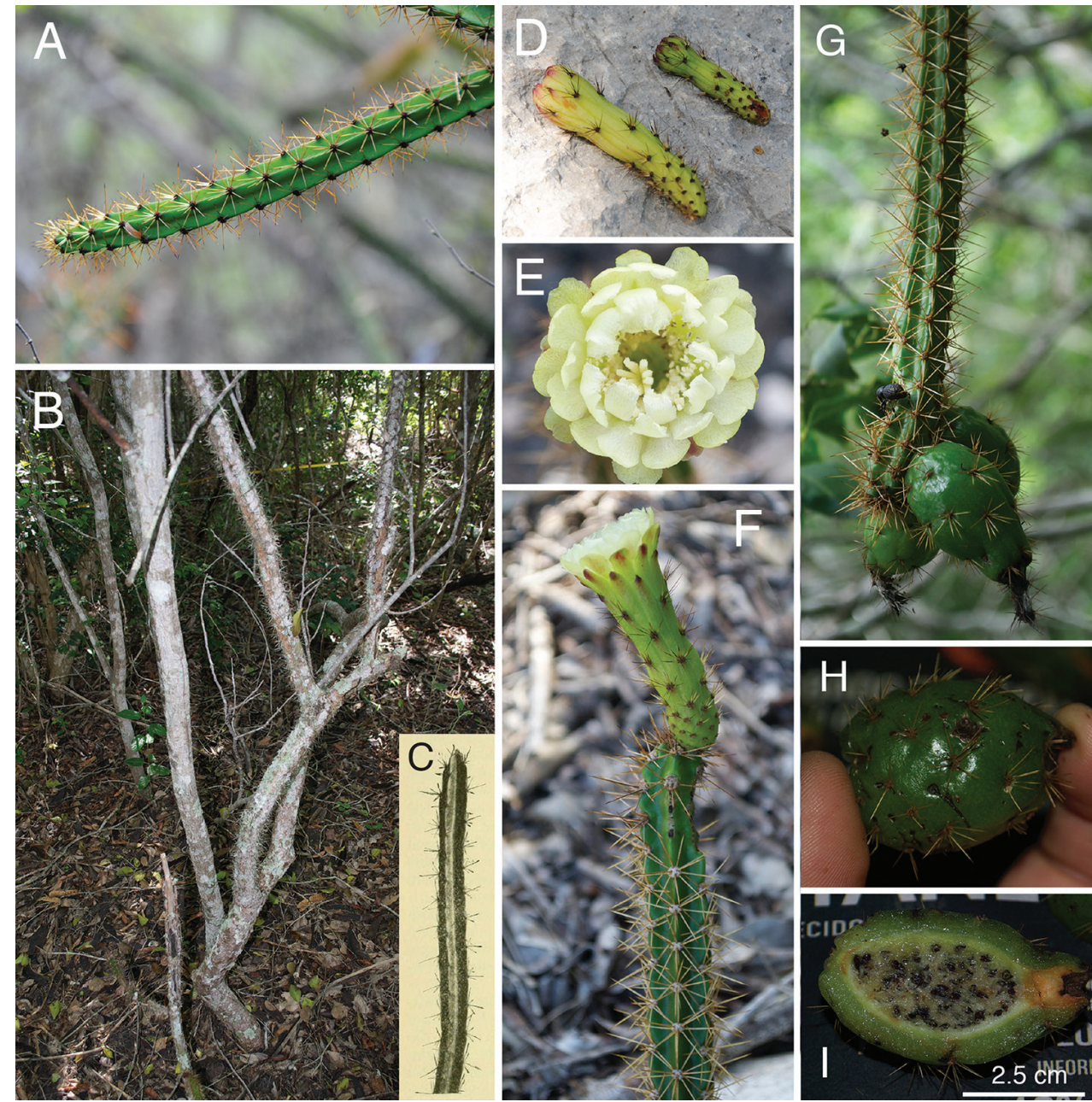

Figure 9. Photographic plate of $L$. weingartianus $\mathbf{A}$ young developing stem showing yellowish spines B trunk of adult individual showing erect growth form $\mathbf{C}$ type of $L$. weingartianus from Hartmann (1904) D floral buds showing spiny pericarpels $\mathbf{E}$ opened flower $\mathbf{F}$ side view of open flower and associated stem showing yellowish spines $\mathbf{G}$ stem with crenate margins and spiny fruit $\mathbf{H}$ shiny, green, spiny fruit with yellowish spines, and I longitudinal section of fruit showing mature seeds. A taken from Majure 7839 B, E, F, H, I from Majure 6464 D from Majure 7863 and G from Majure 6438. Photos by L.C. Majure.

Sierra de Bahoruco, ca. $1.5 \mathrm{~km}$ al este de El Limón en la Carretera 46 al sur del Lago Enriquillo, 43 m, 13 mayo 2019, Majure 7839 (FLAS, JBSD). Parque Nacional Sierra de Bahoruco, Puerto Escondido, Rabo de Gato, 433 m, 13 mayo 2019, Majure 7850 (FLAS, JBSD). Hartr. [Ouest]. Vicinity of Anse Galette, Gonave Island, 3-14 Mar 1920, Leonard 3123 (NY, US). Petite Gonave Island, 9-10 Jul 1920, Leonard 5256 (NY, US). 


\section{Acknowledgements}

We thank El Medio Ambiente for collection and CITES permits for this work and the Jardín Botánico Nacional "Dr. Rafael M. Moscoso" for facilitating this work, including access to collections at JBSD. Brett Jestrow helped with information for several accessions used in this work from FTBG. Mónica Arakaki and an anonymous reviewer provided helpful comments on a previous version of this manuscript. This work was supported in part through grants from the National Science Foundation (J. Franklin GSS-1461496, F. Michelangeli DEB-0818399, L.C. Majure DEB-1735604), the Florida Museum of Natural History Biodiversity Fund to D. Steadman, start-up funds to L.C. Majure (UF/FLMNH), travel funds from the Desert Botanical Garden and a National Geographic Society Explorer's grant to L.C. Majure (grant 9939-16). This work is part of a larger collaborative project to develop a systematic and evolutionary understanding of the cacti of the Greater Antilles.

\section{References}

Anderson EF (2001) The cactus family. Timber Press, Portland, 776 pp.

Areces-Mallea AE (2017) Leptocereus demissus, a new species from southwestern Hispaniola. Cactus and Succulent Society Journal 89(3): 115-121. https://doi.org/10.2985/015.089.0303 Areces-Mallea AE (2018) New taxa of Leptocereus (Cactaceae: Cactoideae) from Western Cuba. Cactus and Succulent Society Journal 90(4): 258-266. https://doi.org/10.2985/015.090.0404

Banda-R K, Delgado-Salinas A, Dexter KG, Linares-Palomino R, Oliveira-Filho A, Prado D, Pullan M, Quintana C, Riina R, Rodríguez MGM, Weintritt J, Acevedo-Rodríguez P, Adarve J, Álvarez E, Aranguren BA, Arteaga JC, Aymard G, Castaño A, Ceballos-Mago N, Cogollo A, Cuadros H, Delgado F, Devia W, Dueñas H, Fajardo L, Fernández A, Fernández MA, Franklin J, Freid EH, Galetti LA, Gonto R, González-M R, Graveson R, Helmer EH, Idárraga A, López R, Marcano-Vega H, Martínez OG, Maturo HM, McDonald M, McLaren K, Melo O, Mijares F, Mogni V, Molina D (2016) Plant diversity patterns in neotropical dry forests and their conservation implications. Science 353(6306): 1383-1387. https://doi.org/10.1126/science.aaf5080

Barrios D, Arias S, González-Torres LR, Majure LC (2020) Phylogeny and taxonomy of the genus Leptocereus (Cactaceae) inferred from chloroplast markers and morpho-anatomical evidence. Plant Systematics and Evolution 306: e63. https://doi.org/10.1007/s00606-020-01693-5

Britton NL, Rose JN (1920) The Cactaceae: descriptions and illustrations of the cactus family. Publication No. 248, The Carnegie Institution of Washington, Washington. https://doi. org/10.5962/bhl.title.45556

Fryxell PA, Clase T (2007) Akrosida floribunda (Malvaceae), a new arborescent mallow from the Dominican Republic. Brittonia 59(4): 385-388. https://doi.org/10.1663/0007-196X(200 7)59[385:AFMANA]2.0.CO;2

Gentry AH (1982) Neotropical floristic diversity: Phytogeographical connections between Central and South America, Pleistocene climate fluctuations, or an accident of Andean orogeny? Annals of the Missouri Botanical Garden 69(3): 557-593. https://doi.org/10.2307/2399084 
Hartmann E (1904) Cereus weingartianus n. sp. Monatsschrift für Kakteenkunde 14: 155-158. Hunt DR, Taylor NP, Charles G (2006) The New Cactus Lexicon. DH books, Milborne Port.

Katoh K, Standley DM (2016) A simple method to control over-alignment in the MAFFT multiple sequence alignment program. Bioinformatics (Oxford, England) 32(13): 1933-1942. https://doi.org/10.1093/bioinformatics/btw108

Köhler M, Reginato M, Souza-Chies TT, Majure LC (2020) Next-generation sequencing across Opuntioideae (Cactaceae): Insights into plastome structural variation and phylogenetic markers in a prickly group. Frontiers of Plant Science 11: e729. https://doi.org/10.3389/ fpls.2020.00729

Lamarck JB de (1785) Dictionnaire encyclopédique de botanique 1: 536-544.

Majure LC, Judd WS, Soltis PS, Soltis DE (2017) A taxonomic revision of the Opuntia humifusa complex (Opuntia s.s.: Cactaceae). Phytotaxa 290: 1-65. https://doi.org/10.11646/ phytotaxa.290.1.1

Majure LC, Baker M, Cloud-Hughes M, Salywon A, Neubig KM (2019) Phylogenomics in Cactaceae: A case study using the chollas sensu lato (Cylindropuntieae, Opuntioideae) reveals a common pattern out of the Chihuahuan/Sonoran desert. American Journal of Botany 106(10): 1-19. https://doi.org/10.1002/ajb2.1364

Majure LC, Clase T, Testo W, Cinea W, Peguero B (2020) Nuevos reportes para la flora de La Española. Moscosoa 20: 151-161.

Martínez-Gordillo M, Clase T, Fragoso-Martínez I (2020) Helicteres pegueroi (Malvaceae: Helicteroideae): a new species from the dry forests of the Dominican Republic. Phytotaxa 438(1): 1-5. https://doi.org/10.11646/phytotaxa.438.1.1

Mejía M, García R (1997) Una nueva especie de Melocactus (Cactaceae) para la Isla Española. Moscosoa 9: 12-17.

Mottram R (2002) Charles Plumier, the King's Botanist - his life and work. With a facsimile of the original cactus plates and text from Botanicon Americanum (1689-1697). Bradleya 20(20): 79-120. https://doi.org/10.25223/brad.n20.2002.a12

Pennington RT, Prado DE, Pendry C (2000) Neotropical seasonally dry forests and Pleistocene vegetation changes. Journal of Biogeography 27(2): 261-273. https://doi.org/10.1046/ j.1365-2699.2000.00397.x

Pennington RT, Lavin M, Prado DE, Pendry CE, Pell SK, Butterworth CA (2004) Historical climate change and speciation: Neotropical seasonally dry forest plants show patterns of both Tertiary and Quaternary diversification. Philosophical Transactions of the Royal Society of London. Series B - Biological Sciences 359(1443): 515-537. https://doi.org/10.1098/rstb.2003.1435

Pennington RT, Lavin M, Prado DE, Pendry CA, Pell SK (2005) Climate change and speciation in neotropical seasonally dry forest plants. In: Malhi Y, Phillips O (Eds) Tropical Forests and Global Atmospheric Change, 199-214. https://doi.org/10.1093/acprof:o so/9780198567066.003.0017

Stamatakis A (2014) RAxML version 8: A tool for phylogenetic analysis and post-analysis of large phylogenies. Bioinformatics (Oxford, England) 30(9): 1312-1313. https://doi. org/10.1093/bioinformatics/btu033

Thiers B (2017) Index Herbariorum: a global directory of public herbaria and associated staff. New York Botanical Garden's Virtual Herbarium. http://sweetgum.nybg.org/scien ce/ih/ 


\section{Appendix I}

Species sampled in our phylogenetic analysis and GenBank accession numbers. Collector and collector number are given, or Desert Botanical Garden (DBG) accession number, as well as herbarium repository in parentheses. Herbarium acronyms follow Thiers (2017).

Armatocereus procerus DBG1994 (DES-SAMN16988911); Calymmanthium substerile DBG 2015 (DES-SAMN16988912); Leptocereus demissus Majure 5972 (DES, JBSD-SAMN16988913); Leptocereus grantianus Majure 6972 (FLAS-SAMN16988914); Leptocereus maxonii Majure 7015 (DES, FLAS, HAJB-SAMN16988915); Leptocereus nudiflorus Majure 6857 (DES, FLASSAMN16988916), Majure 7048 (DES, HAJB-SAMN16988917); Leptocereus paniculatus Majure 6003 (DES, FLAS, JBSD-SAMN16988918), Majure 6581 (DES, JBSD-SAMN16988919); Leptocereus quadricostatus Majure 7111 (FLASSAMN16988920); Leptocereus sylvestris Majure 6874 (DES-SAMN16988921); Leptocereus undulosus Majure 6586 (DES, JBSD-SAMN16988922), Majure 7812 (FLAS, JBSD-SAMN16988923); Leptocereus velozianus Majure 7842, 7843, 7851 (FLAS, JBSD-SAMN16988924-SAMN16988926); Leptocereus weingartianus Majure 6438 (DES, JBSD-SAMN16988930), Majure 7839, 7850, 7863 (FLAS, JBSD-SAMN16988927-SAMN16988929); Leptocereus wrightii Majure 7112 (DES, FLAS-SAMN16988931); Melocactus pedernalensis Majure 5976 (DES, JBSD-SAMN16988932); Selenicereus triangularis Majure 6480 (DES, JBSD-SAMN16988933); Stenocereus fimbriatus Majure 6519 (DES, JBSDSAMN16988934). 